\title{
Sparse promises and meager medical representation
}

$\mathrm{M}$ assive political shifts invariably yield a ragtag crew of Parliamentarians, as people who were offered up as cannon fodder are unexpectedly swept into office.

The 2011 federal election proved no exception as political pundits were left mulling the incongruities and merits of an extremely diverse demographic mix of Members of Parliament (MPs). There were, for example, a record seven university students elected to office (including four undergraduates, one of whom is a teenager, two master's students and a doctoral candidate). That was more than the number of selfdescribed "professors" (3). There were also a few musicians, an actor, a gardener, a bartender and a museum tour guide elected as MPs as $61.4 \%$ of eligible Canadian voters trekked to the polls and delivered a majority 167 seats to Prime Minister Stephen Harper's Conservatives (up 24 from the 143 held at dissolution of Parliament).

In a seismic May 2 political shift, voters also delivered 102 seats (up 66) to the New Democrats and made Jack Layton the nation's Official Opposition leader. Decimated were the Liberals, who notched 34 seats (down 43), prompting the resignation of unpopular leader Michael Ignatieff. All but blasted out of the political waters was the Bloc Québécois, who fell to 4 seats from 47, prompting the unceremonious departure of leader Gilles Duceppe. Voters also delivered a historic first seat to the Green Party by electing party leader Elizabeth May in the British Columbia riding of Saanich-Gulf Islands. (There were two independents and three vacancies when Parliament dissolved).

Although health care consistently topped Canadian concerns in campaign polls, it appeared to have little impact on balloting and the medical community will again be sparsely represented within Parliament.

But one physician, newly elected Dr. Kellie Leitch, is widely believed to be on a fast-track to Cabinet after capturing

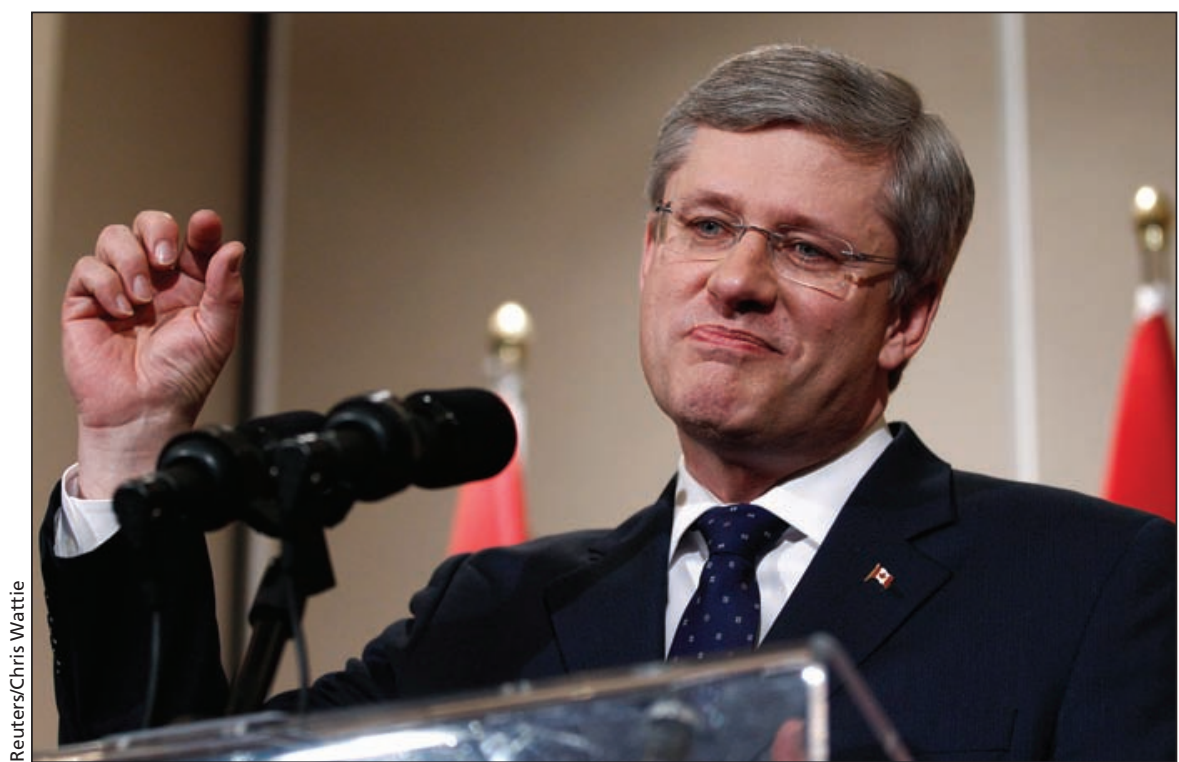

A jubilant Conservative Prime Minister Stephen Harper speaks to reporters in Calgary, Alberta, after winning his first majority government in the $\mathbf{2 0 1 1}$ federal election campaign.

the Ontario riding of Simcoe-Grey, once held by Tory Helena Guergis, who was turfed from Cabinet in 2010 and forced by Harper to resign from caucus over criminal allegations that have since been completely discredited.

Leitch is an orthopaedic pediatric surgeon at SickKids Hospital in Toronto, Ontario and an associate professor at the University of Toronto. She was formerly the chair of pediatric surgery at the Children's Hospital of Western Ontario in London, assistant dean at the Schulich School of Medicine and Dentistry and codirector of the Health Sector MBA (Master of Business Administration) program at the Ivey School of Business.

Her federal and provincial Conservative political ties are extensive. She was once the federal advisor on healthy children and youth, and served as chair of Finance Minister Jim Flaherty's Expert Panel for the Children's Fitness Tax Credit. As founder of the Kids Health Foundation, she is credited with having played a major role in the government's 2010 throne speech commitment to develop a national strategy on childhood injury prevention.
Beyond Leitch, physician representation in the new Parliament will be light, although the Liberals managed to reelect general practitioners Dr. Carolyn Bennett (St. Paul's) and Dr. Hedy Fry (Vancouver Centre).

A doctor from Algeria, Djaouida Sellah, was elected as a New Democrat in the Quebec riding of Saint-BrunoSaint-Hubert. Sellah says on her campaign website that she has been a doctor for more than 10 years and was a founding member and current president of the Association of Quebec Doctors Graduated outside Canada and the United States.

Nine other physicians who sought office, though, saw their political aspirations scuttled. They were:

- Incumbent Dr. Bernard Patry, general practitioner, Liberal, (PierrefondsDollard)

- Dr. John R. Hamilton, ophthalmologist, Liberal (Central Nova)

- Dr. Stan Kutcher, psychiatrist, Liberal (Halifax)

- Dr. Chris Milburn, general practitioner, Green Party (West Nova)

- Dr. Bruce Robert Petty, ophthalmologist, Conservative (Halifax West) 
- Dr. Georgina Wilcock, gynecologist, Green Party (Don Valley West)

- Dr. Scott Edward Daley, general practitioner, Green Party (NipissingTimiskaming)

- Dr. Wendy Wilson, general practitioner, New Democrat (Parry SoundMuskoka)

- Dr. M.J. Willard, pathologist, Liberal (Portage-Lisgar)

Faring as unfavourably were nurses. Of 15 candidates with a nursing background, just two prevailed: Conservative Cathy McLeod (re-elected in Kamloops-Thompson-Cariboo) and New Democrat Christine Moore (newly elected in Abitibi-Témiscamingue).

Meanwhile, dentist, Christian missionary and Conservative Harold Albrecht was re-elected (KitchenerContestoga), while chiropractors will again be well represented. Four of seven were elected, led by Gary Goodyear (Cambridge), current Conservative minister of state (science and technology). The other chiropractic winners were Dany Morin, New Democrat (Chicoumti-Le Fjord); Colin Carrie, Conservative (Oshawa); and James Lunney, Conservative (Nanaimo-Alberni).

A quick perusal of candidate biographies also indicates that lawyers will again top the list of professions that will be best represented in the new Parliament, though their ranks were thinned to 46 from 50 .

They were followed by selfdescribed "businesspersons" (42). The review of biographies also indicates that roughly 30 MPs fall into the camp of expolitical aides/consultants/hacks, while at least 21 MPs cut their political teeth at the municipal or provincial level.

As might have been predicted with the New Democrats success, the number of trade unionists (11) and former civil servants (6) appeared to rise substantially, while the number of teachers/educators held at 17 . The number of farmers in Parliament will be unchanged at 16 but the number of engineers rose to 9. As well, 7 MPs identify themselves as having police backgrounds, while 8 call themselves journalists or broadcasters. Also wellrepresented are realtors (4), financial advisors (4) and economists (4), including Harper.

Once again, as meager as health professional representation in the House of Commons were actual health policy commitments made on the hustings by Harper's Conservatives.

Easily their most significant promise was the surprise vow to maintain an unconditional $6 \%$ annual increase in health transfer payments to the provinces once the current intergovernmental health accord expires in 2014 (www.cmaj.ca/cgi/doi/10.1503/cmaj.109 -3865). The Conservatives were careful, though, to stress that their commitment to a $6 \%$ escalator clause was limited to that specified in the recent federal budget (www.budget.gc.ca/2011/plan /Budget2011-eng.pdf). In that budget, which was not approved by Parliament, an increase in federal transfers for health care is prescribed for exactly two years after the accord expires, (i.e., to $\$ 44.7$ billion $2014-15$ and $\$ 47$ billion in 2015-16).

The Conservatives also reiterated budget promises to attract doctors, nurses and nurse practitioners to "underserved rural and remote" communities by forgiving students a portion of their Canada Student Loans if they agree to work in isolated environments, commencing in fiscal 2012/13. The Conservatives did not define what constitutes such communities while proposing that graduating medical students be eligible to have $\$ 8000$ per year written off their loans, to a maximum $\$ 40000$, and that nurses and nurse practitioners be eligible for a $\$ 4000$ per year write-off, to a maximum $\$ 20000$, if they undertake a stint in a remote community.

The Conservatives also reiterated their plans to establish a nonrefundable tax credit of $\$ 2000$ for Canadians providing care to infirm or dependent relatives.

Essentially, those caring for loved ones meeting certain criteria will get a tax credit of $\$ 2000$. But as with existing health-related tax support, it will be reduced by $15 \%$ for every dollar earned by the person receiving care. For example, someone providing care to an elderly parent is now eligible for $\$ 4385$ in existing tax support. The new caregiver tax credit bumps that up to $\$ 6385$. But if the parent has a pension, the total will be reduced by $15 \%$ of whatever monies the parent received or earned, with the aggregated tax credit and benefits disappearing entirely once the parent's income tops $\$ 21360$. The credit will be added to existing health-related tax supports (www.cmaj.ca/cgi/doi /10.1503/cmaj.109-3856). — Wayne Kondro, $C M A J$

CMAJ 2011. DOI:10.1503/cmaj.109-3892 